\title{
SOSIALISASI DAN PENYULUHAN PEMBAGIAN WARISAN BERDASARKAN HUKUM PERDATA DAN ILMU HUKUM LAINNYA DI DESA TUMBANG RUNGAN
}

\section{(The Socialization And The Delivery Of Information Of The Divisions Of Legacy Based On The Law Of Civil And The Other Laws In The Village Tumbang Rungan)}

\author{
Achmadi, Ratna Atnawatie dan Maimunah \\ Program Studi Ahwal Al - Syakhsiyah Fakultas Agama Islam \\ Universitas Muhammadiyah Palangkaraya \\ JI. RTA Milono Km.1,5 Palangka Raya, Kalimantan Tengah 73111
}

e-mail : achmadiump@gmail.com, ratna.atnawatie17@gmail.com, maybaimhendry@gmail.com

Abstract

Diverse problems appear in the lives of the village are definitely wants solving or a solution that as soon as and as soon as possible in order keep comfort and peace village itself. Responsibility to the various problems arising concerning the interests of the village community of attached to themselves the village $h$ ead itself. Thus the various problems arising in the village ideally the village head act first as arbiter or umpire in resolve any dispute that occurred.

Inheritance already goods of talk about the existence of, the significant events in certain societies, namely the presence of a member of societies or families that have died. A human being as a member of the community, throughout the whole life course, have their place in society with accompanying all the rights and the obligations upon those who were the other members of the community as from the accursed and who are in the community.

The division of property inheritance often lead to problems in daily life. This problem often arose because the one of the parties who felt dissatisfied with the division of inheritance he received. This arises from the nature of greedy humans who always desirous to get more of what has been gotten. To get the estate of inheritance in accordance with the number of desired, the heirs traveled every way that can be done to achieve its goal, either through a legal manner and with against the law

Key note : Inheritance, the heirs

Abstrak

Beragam permasalahan yang timbul dalam kehidupan masyarakat desa sudah pasti menghendaki pemecahan atau solusi yang secepat dan sesegera mungkin dalam rangka menjaga kenyamanan dan ketentraman desa itu sendiri. Tanggung jawab terhadap berbagai permasalahan yang timbul menyangkut kepentingan masyarakat desa tentu melekat pada diri Kepala Desa itu sendiri. Dengan demikian berbagai permasalahan yang timbul di desa tersebut idealnya Kepala Desa bertindak terlebih dahulu sebagai penengah atau wasit dalam menyelesaikan setiap sengketa yang terjadi.

Kewarisan sudah barang tentu membahas tentang adanya kejadian penting dalam masyarakat tertentu, yaitu adanya seorang anggota dari masyarakat atau keluarga yang meninggal dunia. Seorang manusia selaku anggota masyarakat, selama masih hidup, mempunyai tempat dalam masyarakat dengan disertai pelbagai hak-hak dan kewajiban-kewajiban terhadap orang-orang anggota lain dari masyarakat itu dan terhadap barang-barang yang berada dalam masyarakat itu.

Pembagian harta warisan seringkali menimbulkan persoalan dalam kehidupan sehari-hari. Masalah ini sering muncul karena adanya salah satu pihak yang merasa tidak puas dengan pembagian warisan yang diterimanya. Hal ini timbul dari sifat serakah manusia yang selalu berkeinginan untuk mendapatkan yang lebih dari apa yang telah diperolehnya. Untuk mendapatkan harta warisan sesuai dengan jumlah yang diinginkan, para ahli waris menempuh segala cara yang dapat dilakukan guna mencapai tujuannya, baik melalui jalur hukum maupun dengan cara melawan hukum.

Kata Kunci : Kewarisan, Ahli Waris 


\section{PENDAHULUAN}

\section{Analisis Situasi}

Dalam kehidupan masyarakat desa yang penuh dengan kekerabatan dan kekeluargaan tidak menutup kemungkinan terjadi juga permasalahan-permasalahan yang berhubungan dengan kepentingan mereka sendiri di lingkungan perdata seperti masalah pembagian tanah warisan dan pembagian warisan lain yang sering menimbulkan sengketa dalam lingkungan keluarga mereka sendiri. Kekerabatan dan suasana hidup yang penuh kekeluargaan tidak akan dapat memberikan jaminan dalam lingkungan tersebut dapat terjaga untuk selalu hidup dengan suasana nyaman dan tentram. Hal ini disebabkan perkembangan dan kebutuhan yang semakin hari makin menuntut bagi siapapun masyarakat desa untuk selalu siap berkompetisi dalam meningkatkan taraf hidup rumah tangganya sendiri.

Beragam permasalahan yang timbul dalam kehidupan masyarakat desa tersebut sudah pasti menghendaki pemecahan atau solusi yang secepat dan sesegera mungkin dalam rangka menjaga kenyamanan dan ketentraman desa itu sendiri. Tanggung jawab terhadap berbagai permasalahan yang timbul menyangkut kepentingan masyarakat desa tentu melakat pada diri Kepala Desa itu sendiri. Dengan demikian berbagai permasalahan yang timbul di desa tersebut idealnya Kepala Desa bertindak terlebih dahulu sebagai penengah atau wasit dalam menyelesaikan setiap sengketa yang terjadi

Kewarisan sudah barang tentu
membahas tentang adanya kejadian penting
dalam masyarakat tertentu, yaitu adanya seorang anggota dari masyarakat/keluarga yang meninggal dunia. Seorang manusia selaku anggota masyarakat, selama masih hidup, mempunyai tempat dalam masyarakat dengan disertai pelbagai hak-hak dan kewajibankewajiban terhadap orang-orang anggota lain dari masyarakat itu dan terhadap barang-barang yang berada dalam masyarakat itu.

Hubungan-hubungan hukum itu sudah barang tentu tidak lenyap seketika itu, oleh karena biasanya pihak yang ditinggalkan oleh pihak yang wafat tersebut, tidak merupakan seorang manusia atau sebuah barang saja, dan juga oleh karena hidupnya seorang manusia yang meninggal dunia itu, berpengaruh langsung pada kepentingankepentingan beraneka warna dari pelbagai anggota masyarakat, dan kepentingankepentingan ini, selama hidup seorang itu, membutuhkan pemeliharaan dan penyelesaian oleh orang itu. Oleh karenanya timbul yang dinamakan warisan, yaitu cara penyelesaian antar hubungan hukum dalam masyarakat yang melahirkan sedikit banyak kesulitan sebagai akibat dari wafatnya seorang manusia. Dapat dikatakan bahwa perhubungan-perhubungan hukum yang berhubungan dengan wafatnya seseorang dibutuhkan diatur, adalah hanya mengenai kekayaan seorang itu.

Maka dapat ditegaskan selaku pengertian warisan ialah, bahwa warisan itu adalah soal apakah dan bagaimanakah pelbagai hak-hak dan kewajiban-kewajiban tentang kekayaan seorang pada waktu ia meninggal dunia akan beralih kepada orang lain yang masih hidup.

Pembagian harta warisan seringkali menimbulkan persoalan dalam kehidupan seharihari. Masalah ini sering muncul karena adanya 
salah satu pihak yang merasa tidak puas dengan pembagian warisan yang diterimanya. Hal ini timbul dari sifat serakah manusia yang selalu berkeinginan untuk mendapatkan yang lebih dari apa yang telah diperolehnya. Untuk mendapatkan harta warisan sesuai dengan jumlah yang diinginkan, para ahli waris menempuh segala cara yang dapat dilakukan guna mencapai tujuanya, baik melalui jalur hukum maupun dengan cara melawan hukum. Jika perolehan harta warisan diperoleh dengan jalan melawan hukum, maka sudah ada sanksi hukum yang menanti para pihak yang melakukan perbuatan tersebut.

Jika perolehan harta warisan diperoleh dengan jalan sesuai dengan hukum, maka tidak akan ada sanksi hukum yang diberikan. Masalah yang timbul adalah apakah jalan hukum yang ditempuh tersebut memenuhi prinsip keadilan bagi semua pihak yang berperkara. Terutama di dalam masalah warisan, sering kali putusan yang adil bagi salah satu pihak belum tentu dianggap adil oleh pihak yang lain.

\section{Permasalahan}

Khusus sengketa warisan yang sering muncul sebagai salah satu permasalahan yang terjadi di desa merupakan masalah yang menarik untuk dikaji, lebih-lebih sudah menyangkut tentang pembagian warisan, karena umumnya warisan mempunyai nilai ekonomis dan religius yang tinggi. Dengan kata lain warisan dapat menimbulkan kebahagian satu pihak dan di pihak lain dapat menimbulkan kesengsaraan, apabila dalam pengaturan dan pembagian tidak sesuai dengan ketentuan yang seharusnya diikuti bersama. permasalahan-permasalahan tersebut diantaranya sebagai berikut, yaitu:

online : http://jurnal.umpalangkaraya.ac.id/ejurnal/pgbmu
1. Pentingnya akan pembagian harta warisan bagi masyarakat di lingkungan desa Tumbang Rungan.

2. Kurangnya pemahaman masyarakat desa tentang perkembangan ilmu pengetahuan khususnya ilmu hukum perdata yang digunakan dalam hal pembagian harta warisan.

3. Minimnya pengetahuan masyarakat desa tentang pembagian harta warisan baik dari aspek ilmu hukum maupun aspek ilmu agama.

\section{Tujuan}

Tujuan yang ingin dicapai dalam pengabdian kepada masyarakat ini adalah untuk menyebarluaskan informasi-informasi kepada khalayak masyarakat dipelosok desa yang berada dipinggiran sungai Kahayan Kota Palangka Raya mengenai pembagian-pembagian harta warisan. Selain itu, tujuan kegiatan Pengabdian kepada Masyarakat ini adalah untuk memberikan kesempatan kepada para dosen dan mahasiswa untuk turun langsung mengabdi kepada masyarakat dan menjalankan salah satu program lembaga penelitian dan pengabdian kepada masyarakat (LP2M) sebagai kewajiban tridharma perguruan tinggi untuk para dosen dan mashasiswa di UM Palangka Raya.

\section{METODE PELAKSANAAN}

\section{Waktu dan Tempat}

Kegiatan sosialisasi dan penyuluhan hukum ini dilaksanakan dengan tiga tahap, yaitu sebagai berikut:

1. Tahap pertama, pada hari sabtu, tanggal 2 September 2015 ketua tim melakukan observasi ke Desa Tumbang Rungan untuk 
meneliti kebutuhan-kebutuhan masyarakat terkait dengan permasalahan hukum dan keadilan yang diperlukan oleh masyarakat Desa Tumbang Rungan. Setelah melakukan diskusi singkat dengan beberapa warga masyarakat, muncullah beberapa ide dan kehendak yang disampaikan para masyarakat terkait dengan pembagian harta warisan.

2. Tahap Kedua, tim pengabdian kepada masyarakat menyusun proposal pengabdian kepada masyarakat sesuai dengan kebutuhan dari ide dan masukan-masukan masyarakat terkait dengan pembagian harta warisan. Hingga proposal selesai disusun, kemudian proposal di ajukan ke lembaga penelitian dan pengabdian kepada masyarakat (LP2M) UM Palangka Raya untuk dapat diberi bantuan guna menunjang kegiatan tersebut.

3. Tahap Ketiga, setelah proposal pengabdian kepada masyarakat yang telah dimasukkan ke LP2M telah dinyatakan lolos seleksi dan diberikan bantuan biaya pada tanggal 25 November 2015. Maka selanjutnya tim pengabdian masyarakat terjun ke lapangan untuk melakukan penjadwalan pelaksanaan sosialisasi dan penyuluhan dengan menghitung jumlah penduduk guna untuk menyebar undangan kepada calon peserta sosialisasi dan penyuluhan hukum tentang pembagian harta warisan berdasarkan hukum perdata dan ilmu hukum lainnya dilingkungan masyarakat Desa Tumbang Rungan.

Dari 40 undangan yang disebar, hanya berjumlah 33 peserta saja yang hadir saat kegiatan sosialisasi dan penyuluhan pemberian materi-materi tentang pembagian harta warisan menurut pandangan hukum perdata, hukum Islam dan hukum adat dengan menggunakan metode ceramah dan dialog yang kami laksanakan di kantor Kelurahan Tumbang Rungan pada hari rabu, tanggal 6 februari 2016 dengan durasi waktu selama 180 menit (3 jam).

\section{Sasaran Kegiatan}

Desa Tumbang Rungan adalah sebuah desa yang berada di Kelurahan Tumbang Rungan, Kecamatan Pahandut Seberang di Kota Palangkaraya, Provinsi Kalimantan Tengah. Lokasi sasaran Pengabdian Kepada Masyarakat ini dilaksanakan di kantor Kelurahan Tumbang Rungan Desa Tumbang Rungan yang terletak di Daerah Aliran Sungai (DAS) Kahayan yang berjarak tempuh sekitar $8 \mathrm{~km} / \mathrm{jam}$ dari Bundaran Besar (alun-alun pusat Kota Palangkaraya)

Untuk dapat menuju ke Desa Tumbang Rungan bisa menggunakan moda transportasi melalui darat dan sungai baik menggunakan getek (taksi air), atau juga dapat ditempuh dengan menggunakan kendaraan bermotor. Jumlah penduduk di Kelurahan Tumbang Rungan berjumlah 183 kepala keluarga (KK), terdiri dari 566 orang penduduk beragama Islam dan 63 orang penduduk beragama Kristen.

Posisinya yang tidak terlalu jauh dari Kota Palangkaraya, menjadikan keadaan perekenomian masyarakat di desa ini cukup maju. Terlihat dengan banyaknya beberapa fasilitasfasilitas umum yang telah dibangun seperti pasar, tempat ibadah, pelabuhan, dan penunjang telekomunikasi seperti adanya tower jaringan telekomunikasi sebagai bukti kemajuan di Desa Tumbang Rungan. Menurut Kepala Kelurahan Tumbang Rungan Bp. Purwanto S.sos ketika ketua tim pengabdian mengadakan observasi, 
Berdasarkan hasil Musrenbang tahun 2015 Desa Tumbang Rungan ini akan dijadikan sebagai Desa Pariwisata di Kota Palangka Raya.

Adapun target luaran yang ingin dicapai dalam pengabdian kepada masyarakat di Desa Tumbang Rungan adalah sebagai berikut :

1. Masyarakat dapat mengetahui langkah-langkah yang tepat dalam penanganan sengketa pembagian harta warisan.

2. Masyarakat dapat mengetahui dasar-dasar dari ilmu hukum perdata dalam proses pembagian harta warisan.

3. Masyarakat dapat mengetahui dan memahami bahwa terdapat sumber ilmu hukum yang lain, baik dari pandangan hukum agama maupun hukum adat dalam peneyelesaian sengketa pembagian harta warisan.

\section{Metode Kegiatan}

Metode yang digunakan dalam kegiatan pengabdian kepada masyarakat di Desa Tumbang Rungan, Kelurahan Tumbang Rungan, Kota Palangka Raya adalah dengan menggunakan metode: ceramah, dialog dan diskusi serta pemecahan masalah yang terkait dengan pembagian harta warisan secara adil yakni mengenai pembagian menurut pandangan ilmu hukum dan pembagian harta warisan menurut hukum Islam. Melalui gabungan metodemetode tersebut diharapkan peserta tidak hanya mendapatkan materi tentang harta warisan menurut hukum perdata saja akan tetapi juga masyarakat juga mengetahui secara mendalam pembagian harta warisan menurut hukum Islam.

\section{Solusi Yang Ditawarkan}

Dalam konteks Pengabdian Kepada Masyarakat yang dilaksanakan di Desa Tumbang Rungan ini, kami memberikan solusi yang akan ditawarkan, diantaranya sebagai berikut :

1. Memberikan sosialisasi dan penyuluhan tentang langkah-langkah yang tepat dalam penyelesaian sengketa pembagian harta warisan, agar tercapainya rasa keadilan di dalam keluarga.

2. Memberikan penjelasan bagaimana pandangan dari ilmu hukum perdata untuk digunakan dalam pembagian harta warisan.

3. Memberikan pemahaman yang signifikan tentang pembagian harta warisan baik dari aspek ilmu hukum maupun aspek ilmu agama.

\section{HASIL DAN PEMBAHASAN}

Dalam melaksanakan kegiatan pengabdian kepada masyarakat dengan tema "Sosialisasi dan Penyuluhan Pembagian Warisan Berdasarkan Hukum Perdata dan ilmu hukum lainnya di Desa Tumbang Rungan". Telah hadir sekitar $82 \%$ peserta undangan atau 33 orang peserta dari 40 undangan yang disebar. Bukan hanya masyarakat disekitar Desa Tumbang Rungan yang turut hadir tetapi juga antusias para guru dari SDN 1 atap Tumbang Rungan dan salah satu anggota Polri bid.Babinkamtibmas dari Polsek Pahandut. Antusias peserta yang hadir sebanyak $82 \%$ menandakan bahwa keberhasilan dalam melaksanakan kegiatan disambut baik oleh masyarakat.

Lancarnya kegiatan pengabdian kepada masyarakat ini menunjukkan bahwa secara umum tujuan dari kegiatan tercapai, meskipun di 
lapangan dijumpai adanya beberapa hambatan. Hambatan tersebut adalah sulitnya menentukan hari untuk pelaksanaan kegiatan dikarenakan banyak para peserta yang sulit menyepakati waktu yang tepat untuk pelaksanaan kegiatan. Menentukan waktu memang bukan persoalan yang mudah. Kondisi tersebut dapat dikatakan menyebabkan mundurnya waktu kegiatan Pengabdian Kepada Masyarakat ini, khususnya penentuan agenda sosialisasi dan penyuluhan hukum tersebut.

Hambatan lain adalah sulitnya mempertahankan jumlah peserta kegiatan. Hal tersebut disebabkan karena dipengaruhi kondisi keadaan cuaca yang kebetulan pada pelaksanaannya sedang hujan lebat dan sebagian masyarakat lainnya dengan berbagai pekerjaan dan rutinitas masyarakat setempat sebagai nelayan, petani karet, pedagang, dan pegawai-pegawai dilingkungan kelurahan, setempat sehingga waktu yang mereka miliki terbatas.

Melalui peningkatan pengetahuan, pemahaman serta kemampuan para masyarakat di Desa Tumbang Rungan terkait dengan permasalahan pembagian harta warisan, maka harapan ke depan adalah bertambahnya ilmu pengetahuan yang diserap masyarakat dari pelaksanaan sosialisasi dan penyuluhan hukum terhadap masalah pembagian harta warisan, sehingga ke depan tidak ada lagi perselisihanpersilihan yang muncul di dalam keluarga akibat dari pembagian harta warisan secara adil dan merata di dalam sebuah keluarga.

Faktor Pendukung dan Penghambat Kegiatan.

1. Faktor pendukung kegiatan pengabdian kepada masyarakat ini, yakni: a. Bagi masyarakat setempat tema tentang pembagian harta warisan ini merupakan tema yang menarik, sebab tema tersebut sampai saat ini masih selalu aktual. Oleh karena itu, masyarakat cenderung bersikap proaktif dengan dilaksanakannya kegiatan pengabdian kepada masyarakat karena temanya aktual dan terkait dengan realita yang akan dihadapi masyarakat.

b. Antusiasme peserta terhadap pengetahuan/issue-issue baru terutama yang berkaitan dengan pembagianpembagian harta waris. Hal inilah yang menyebabkan kegiatan pengabdian kepada masyarakat, khususnya pada saat berlangsungnya kegiatan yaitu dengan diskusi dan pemecahan kasus menjadi hidup.

2. Faktor penghambat kegiatan pengabdian pada masyarakat, yakni:

a. Sulitnya menentukan hari untuk pelaksanaan kegiatan dikarenakan banyak para peserta yang sulit menyepakati hari yang kami sarankan antara hari sabtu atau minggu untuk pelaksanaan kegiatan. Pada hari libur justru banyak kegiatan digunakan untuk kepentingan keluarga masingmasing. Ditambah lagi dengan ketika saat pelaksanaan kegiatan keadaan cuaca yang turun hujan lebat.

b. Sulitnya mempertahankan jumlah peserta kegiatan pada hari pelaksanaan. Hal tersebut disebabkan karena faktor cuaca yang saat pelaksanaan kegiatan keadaan cuaca sedang turun hujan lebat dari pagi hari dan karena sebagian peserta juga banyak yang menjalankan rutinitas sehari- 
hari sehingga jumlah peserta tidak lagi utuh sebanyak 40 peserta yang ditargetkan.

Berdasarkan hasil yang diperoleh dari kegiatan ini, peserta sosialiasi telah merasakan manfaatnya, yakni memiliki tambahan pengetahuan dan pemahaman terkait dengan pembagian-pembagian harta warisan yang dianjurkan sesuai dengan Al-Qur'an dan KUHPdt bagi masyarakat yang beragama Islam di lingkungan masyarakat di Desa Tumbang Rungan Kota Palangka Raya.

Hasil Fisik yang Bermanfaat Bagi Masyarakat.

Adapun hasil-hasil yang dicapai dan bermanfaat dalam pengabdian kepada masyarakat di Desa Tumbang Rungan adalah sebagai berikut :

a. Masyarakat memperoleh materi-materi sosialisasi dan penyuluhan serta mengetahui secara komprehensif langkah-langkah yang tepat dalam penanganan sengketa pembagian harta warisan.

b. Masyarakat mengetahui dasar-dasar dari ilmu hukum perdata, hukum Islam, dan hukum adat dalam sebuah proses pembagian harta warisan.

c. Hasil diskusi kelompok sebagai bahan kajian pemecahan permasalahan pembagian harta warisan dalam upaya penyadaran hukum terhadap asas keadilan bagi masyarakat.

\section{Tanggapan dan Keaktifan Masyarakat terhadap kegiatan Pengabdian Kepada Masyarakat.}

Kegiatan sosialisasi dan penyuluhan hukum tentang pembagian harta warisan ini ditanggapi positif dan antusias oleh para masyarakat Desa Tumbang Rungan sebagai peserta aktif. Hal ini terbukti dengan banyaknya pertanyaan-pertanyaan yang muncul dan diskusi serta dialog-dialog ringan setelah pemateri menyampaikan ceramah hingga sampai kegiatan selesai.

Pertanyaan-pertanyaan yang ditanyakan oleh peserta Pengabdian Kepada Masyarakat dan jawaban yang diberikan oleh para pemateri adalah sebagai berikut:

1. Bagaimana pembagian harta jika suami meninggal dan si suami mempunyai lebih dari 1 orang isteri?

Jawab: Pembagian harta warisannya dihitung semenjak ia menikah dengan suaminya. Misalnya si $\mathrm{A}$ adalah isteri pertama, dan si $\mathrm{B}$ sebagai isteri kedua, maka pembagian harta warisannya dihitung semenjak ia menikah sampai suami meninggal dunia.

Pembagian harta warisannya yaitu : 1/4 kalo tidak memiliki anak dan 1/8 kalo isteri memiliki anak.

Kalo untuk isteri yang kedua si B penghitungannya sama halnya dengan isteri yang pertama semenjak ia menikah sampai suami meninggal dunia. Baru kemudian dihitung pembagiannya sesuai dengan hukum Islam.

2. Warisan yang dibagikan setelah melunasi hutang piutang. Bagaimana hukumnya jika hutang pinjaman di bank yang akadnya lunas ketika si peminjam meninggal dunia?

Jawab: "Kalo akadnya demikian, berarti berlakulah hukumnya demikian. Karena kalo pinjaman di bank itu biasanya disertai dengan asuransi jiwa bagi peminjamnya, maka jika peminjamnya meninggal dunia, selanjutnya pihak asuransi yang melanjutkan pembayarannya. 


\section{SIMPULAN DAN SARAN}

\section{Simpulan}

Berdasarkan rancangan dan kegiatan Pengabdian Kepada Masyarakat dengan tema "Sosialisasi dan Penyuluhan Pembagian Warisan Berdasarkan Hukum Perdata dan ilmu hukum lainnya di Desa Tumbang Rungan di Kelurahan Tumbang Rungan, dapat disimpulkan bahwa :

1. Kegiatan Pengabdian Kepada Masyarakat yang dilaksanakan selama 1 hari dalam bentuk sosialisasi dan penyuluhan hukum terhadap pembagian harta warisan ini dapat berjalan dengan baik dan lancar, meskipun tidak terlepas pula dari beberapa hambatan dan keterbatasan dilapangan.

2. Para peserta kegiatan Pengabdian Kepada Masyarakat yang hadir cukup bersemangat dalam mengikuti jalannya sosialisasi dan penyuluhan hukum, sebab tema yang disajikan sangat aktual dan hampir dari keseluruhan masyarakat Desa Tumbang Rungan masih belum mengetahui mekanisme dan tata cara dalam pembagian harta warisan.

\section{Saran}

Perlu ditingkatkannya lagi "Sosialisasi dan Penyuluhan Pembagian Warisan Berdasarkan Hukum Perdata dan ilmu hukum lainnya terutama di daerah atau desa-desa lain yang sasaran masyarakatnya sudah memilik tingkat perekonomian yang baik, sehingga dapat diharapkan masyarakat sudah memahami tentang tata cara pembagian harta warisan kepada para ahli waris.

\section{DAFTAR PUSTAKA}

Abdoel Djamal. (2000), Pengantar Hukum di Indonesia. Jakarta: Raja Grafindo Persada.

Depag RI. (1991), Badan Peradilan Agama, Kompilasi Hukum Islam, Bandung: Humaniora Utama Press.

H. Hilman Hadikusuma. (1983). Hukum Waris Adat, Bandung: Alumni.

M. Ali Ash Shabuny, (2013). Hukum Waris Dalam Islam, Jakarta: Fathan Prima Media.

Perangin, Effendi. (2010), Hukum Waris, Jakarta: Rajawali Pers.

Tim. Hasby Ash Shiddieqy, (2011). Fiqh Mawaris, Jakarta: Pustaka Rizky Putra.

Wirjono Prodjodikoro. (1991). Hukum Warisan di Indonesia. Bandung:Sumur. 